Article

\title{
Decolonial Possibilities of Reintroducing the Devil in the Public Space of Afro-Ecuadorian Territories
}

\author{
María Gabriela López-Yánez ${ }^{1, *}$ and María Paz Saavedra Calderón ${ }^{2}$ \\ ${ }^{1}$ School of Dance, Faculty of Arts, Central University of Ecuador, Ecuador; E-Mail: mglopezy@uce.edu.ec \\ 2 Kimia-Pedagogías Críticas, Ecuador; E-Mail: paz.saav.c@gmail.com \\ * Corresponding author
}

Submitted: 14 April 2021 | Accepted: 4 October 2021 | Published: 30 November 2021

\begin{abstract}
The article discusses the decolonial possibilities of the collective design of a sound artwork in reimagining the role of two Afro-Ecuadorian music and dance-based events in the Afro-Ecuadorian ancestral territories of North Esmeraldas and Chota-Mira. The two events, Bomba del Chota and Marimba Esmeraldeña, emerged in the context of slavery and colonialism as a response of Afro-Ecuadorians to the oppression and violence they endured. These two music and dance-based events sustain a counter-narrative of power and resistance for Afrodescendant peoples in Ecuador, weaving meaningful connections among them and other entities populating their territories, such as the "devil," whose cohabitation with Afro-Ecuadorians will be at the spotlight of our analysis. Based on the audio-recorded testimonies of these connections that strongly existed until the 1970s, and of a sonic composition that was created from them, we propose a collaborative design of a sound artwork in the public spaces of the jungle in Esmeraldas and the mountain in Chota-Mira. We discuss how a decolonial approach to the design of the artwork can serve as a dialogical space to engage inhabitants in their re-connection to the possibilities of resistance that their ancestors nurtured in their territories through the practice of the two music and dance-based events. Through a political reading of soundscapes, an argument is developed to show how sound constructs the public spaces that root people in their territories, connecting them with meaningful stories and practices that keep being forgotten due to the on-going consequences of slavery and colonialism. The article contributes to the discussion about political ecologies and the collective production of public spaces as a joyful response to exclusion and oppression.
\end{abstract}

\section{Keywords}

Afro-Ecuadorians; ancestral practices; Bomba; decoloniality; Marimba; representations of the devil; sound artwork; soundscapes

\section{Issue}

This article is a part of the issue "Art and Design for Social Inclusion in the Public Sphere" edited by Karin Hannes (KU Leuven, Belgium).

(C) 2021 by the authors; licensee Cogitatio (Lisbon, Portugal). This article is licensed under a Creative Commons Attribution 4.0 International License (CC BY).

\section{Introduction}

In this article, we discuss the decolonial possibilities of the collective design of a dialogic sound artwork through reimagining the role of the Afro-Ecuadorian music and dance based-events Marimba Esmeraldeña and Bomba del Chota in shaping the public spaces in the two ancestral Afro-Ecuadorian territories of North Esmeraldas and Chota-Mira Valley. Afrodescendants' communities in Ecuador created these two events during the period of Atlantic slavery that lasted from the 16th to the 19th century. Since slavery and beyond, communities have conceived Marimba Esmeraldeña and Bomba del Chota not just as music and dance genres but also as intimate, joyful, and communal practices of momentary liberation from the oppressive systems of the slavery and post-slavery periods. One of the key features of these events, and the liberatory possibilities they open, 
resides in the relationship they have maintained with "the devil," which will be the focus of this article. Elders from Afro-Ecuadorian communities portray the devil as an uninvited guest in their celebrations that involve Marimba and Bomba. This guest (a male figure) appears each time he sees the opportunity to charm the participants in these events through his singing and dancing, and to distract them while he flirts and even kidnaps female attendees. Most of the testimonies, however, also point out the fact that there has always been the possibility of noticing his presence and defeating him through chants and prayers, or by proving they are better singers and dancers than him. These actions make the devil disappear. In this article, we read the ability of Marimberos and Bomberos to defeat the devil as a way of opening spaces for the transgression of the colonial power represented by the Christian figure of the devil. Moreover, we suggest that such playful and defiant cohabitation with the devil enacts a different form of community-building that fosters collective empowerment in response to colonialism.

Despite the richness of the practices related to the two music and dance-based events, from the 1970s onward it has been less frequent to see younger generations engaging in them. Nowadays, they are almost completely forgotten among young Afro-Ecuadorians. This discontinuity means that the connection to creatures such as the devil are no longer part of people's interaction with their territories, thus no longer shaping the public space. Nonetheless, elders from most Afro-Ecuadorian communities recall this connection to the non-human world, via their relationship with the devil, through their embodied memories of music and dance. We will use audio recorded conversations with community elders about the devil, and a sonic composition made from them, as the central material for the collaborative design of a sound artwork aiming to re-engage people with these stories (see Figure 1).

By collectively designing the "reintroduction of the devil" into these territories, we want to explore the decolonial possibilities of inhabiting and shaping the public space. We discuss the decolonial potential of constructing a space with and for the communities to reconnect to these counter-narratives cultivated throughout generations in the practices of Marimba and Bomba. Through a political reading of soundscapes, an argument is developed to show how sound "constructs" the public space that roots people to their territories, connecting them with meaningful stories and practices that tend to be forgotten due to the consequences of slavery and colonialism.

The article starts with a contextualisation of the music and dance events in the two ancestral territories.
It then focuses on the story and relevancy of the concept of the devil. Afterwards, the connection to the devil in the decolonial framework is discussed, and some important methodological aspects explained. The discussion opens to the practical and conceptual possibilities of our proposal. The article ends with concluding remarks on the possibilities of a decolonial conception of this sound artwork and how it can transform the public space.

\subsection{Historical Context}

According to the last population census, Afro-Ecuadorians represent $7.2 \%$ of the Ecuadorian population (INEC, 2010). From the period of Atlantic slavery, both enslaved and freed Africans, as well as their descendants, populated principally two areas in Ecuador: the Chota-Mira river basin (a valley in the northern Andean region) and the northern part of Esmeraldas province (the northwest coastal province, on the frontier with Colombia). Despite the current presence of Afro-Ecuadorians all over the national territory, this article refers specifically to the two ancestral territories Afro-Ecuadorians' ancestors first inhabited. The main reason for this selection is that the two music and dance-based events originated in these territories and most of their narratives and sounds are embedded in the ecologies of the two territories: Marimba Esmeraldeña in North Esmeraldas and Bomba del Chota in Chota-Mira Valley.

The two Afro-Ecuadorian ancestral territories are rural areas far away from major urban centres. The ancestral territory in Esmeraldas is mainly constituted by tropical forest, whereas the territory of Chota-Mira Valley is mainly dry forest. However, both these territories have been deteriorating over the years. In Esmeraldas, this deterioration has occurred due to the mining of transnational companies affecting water and soil; in Chota-Mira, it has been due to intensive agro-industrial production which has polluted the water and the soil, as well as the closeness of the villages to the highway. The two territories are thus shaped by the intermittent sounds and silences of mountains and rivers, but also of agro-industrial and mining machines, buses (in Chota-Mira), and motorboats (in North Esmeraldas). Although rivers, mountains, and other non-human entities inhabit these territories, the pollution caused by mining and agro-industrial activities has changed the relation of the people to them, making it, for instance, less safe for them to drink water, swim, or fish in the river. According to conversations held between Marimberos, Bomberos, and López-Yánez (2020), similar ecological reasons are affecting life and cohabitation in these territories, forcing the devil and other creatures out-if they haven't left already.

Recording of conversations $\quad \sum$ Sonic Composition $\quad>\begin{gathered}\text { Collaborative design } \\ \text { of the artwork }\end{gathered}$

Figure 1. Creation process. 
The story of the arrival of enslaved African people to Chota-Mira Valley starts at the beginning of the 17th century with the Jesuits, a Catholic order of priests, who introduced enslaved African people in vast numbers to the area. As for the arrival of enslaved Africans to North Esmeraldas, it is marked by the shipwrecks of boats carrying enslaved Africans that reached the Ecuadorian coast, the most famous one being that which happened in the mid-16th century (Cabello Balboa, 1583/1945, pp. 18-19). The group of enslaved people that have reached the coastal area of Ecuador, mainly through this last shipwreck, inhabited it as freed people. They remained free until the mid-18th century, when mines were established in Esmeraldas and, with that, the first enslaved Afrodescendant people were also introduced to the area.

Afro-Ecuadorians in their two ancestral territories remained enslaved until a long process of manumission and intense struggle occasioned the official abolition of slavery in Ecuador in 1852. However, even after the official emancipation of black people in Ecuador, many Afro-Ecuadorians' living conditions did not improve greatly. Afro-Ecuadorians have remained one of the most impoverished groups of people since the colonial period (CEPAL \& UNFPA, 2020; Fundación Azúcar, 2017). Furthermore, due to the historical, social and geographical isolation of Chota-Mira and North Esmeraldas, almost all of its inhabitants have remained Afrodescendants, so they are still known as Afrodescendants' territories. Embedded in this colonial history of neglect and systemic racism, there is the common perception of people living outside these two territories that they are places of violence, laziness, backwardness, and unconquered nature (Rahier, 1998, p. 423, 2011, p. 68). This historical reality has impeded many Afro-Ecuadorians to have dignified living conditions and access to education (Figure 2). It is within this context that we need to understand the role of the devil and its connection to the two territories.

\subsection{The Sound of Memories}

According to the Afro-Ecuadorian thinker García Salazar's lifelong research, oral transmission is the primary source of sharing the lived knowledge, stories, experiences, and thoughts of peoples of African origin who settled in the Ecuadorian Chocoan jungle and Andean region almost 500 years ago (García Salazar, 2020; García Salazar \& Walsh, 2017). Oral traditions refer to the semantic meaning of words and to the pauses, sighs, intonations, and specific rhythms while speaking. Thus, Marimberos and Bomberos reproduce their oral traditions through their intimate interpretations and understandings of Marimba and Bomba. Oral traditions are so significant for Afro-Ecuadorians that García Salazar affirmed that some Afro-Ecuadorians' knowledge is only meant to be heard, since this knowledge loses strength and even meaning when it is transferred into written words (García Salazar \& Walsh, 2017). Importantly, the fact that knowledge has not been transmitted by Marimberos and Bomberos in written form until recently has been circumstantial
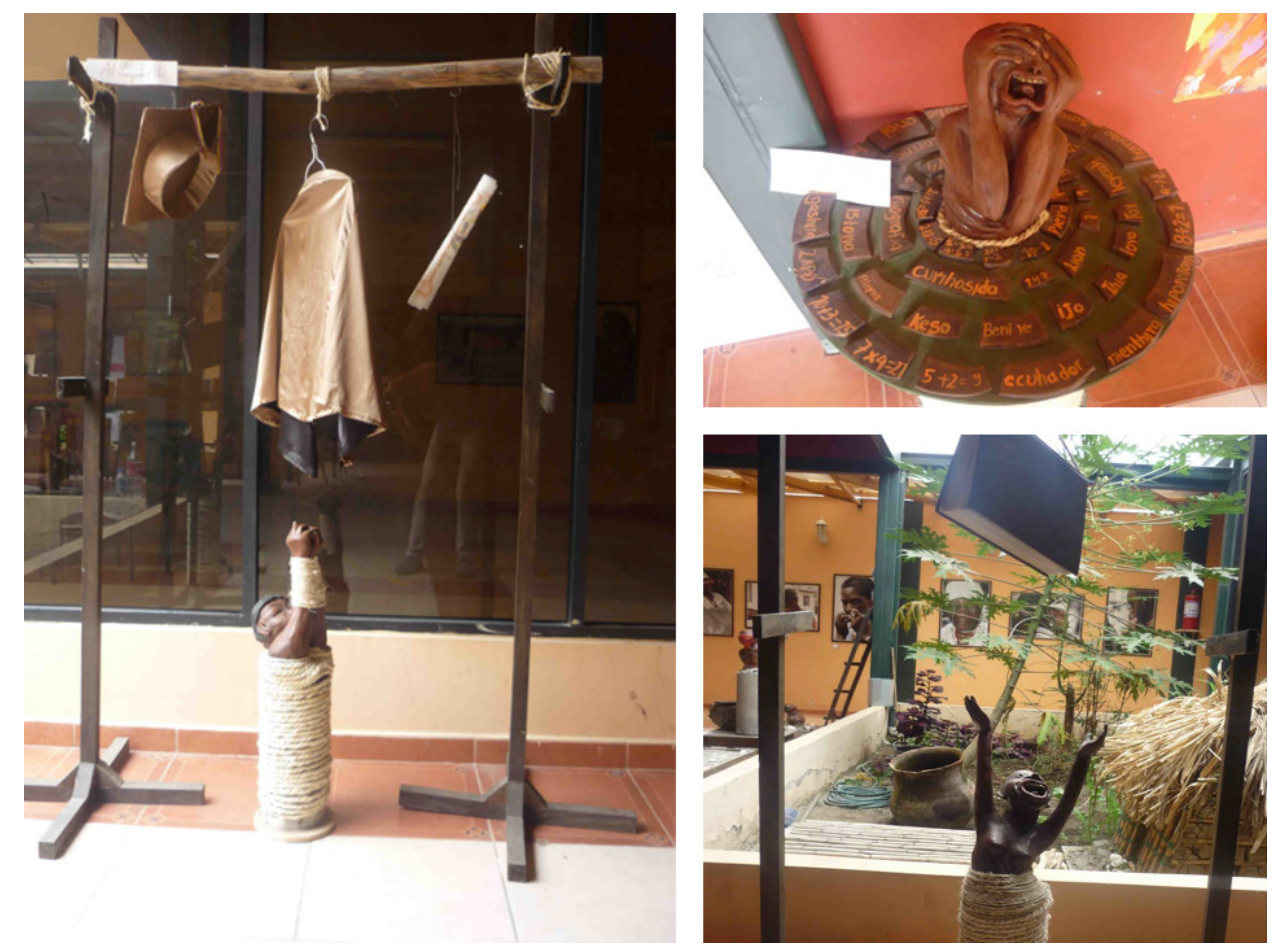

Figure 2. Artworks about the lack of access to a good quality education for most Afro-Ecuadorians. Author of all the sculptures: Alicia Villalba. Photographs taken by María Gabriela López-Yánez during an exhibition of the Afro-Choteño artist, which took place in the Afro-Choteño community of Juncal in 2012. 
to slavery and not necessarily a product of choice. As explained by Quijano (1992, p. 13), enslaved people were forcefully kept illiterate and condemned to only communicate orally. The Afro-Esmeraldeño writer and activist Juan Montaño also affirms that orality was a necessity (and sometimes still is) for Afro-Ecuadorians because the oppressor took away all other means of documentation (J. Montaño, personal communication, 2018). Even in post-slavery periods, most of the elder Marimberos and Bomberos have never written down their memories before and some of them are illiterate (López-Yánez, 2020). One of the few exceptions is the book Memoria Viva: Costumbres y tradiciones Esmeraldeñas (Escobar Quiñónez et al., 1997) in which the collective memories of the renowned Marimbero Remberto Escobar were transcribed.

Regarding our relationship as researchers to AfroEcuadorians' and their oral memories, we follow what Bolivian sociologist Rivera Cusicanqui $(1987,2015,2018)$ has named relación de escucha (a "listening relationship") and defines as a "collective exercise of disalienation" (Rivera Cusicanqui, 2015, p. 286). With a collective exercise of disalienation, Rivera Cusicanqui refers to a long-term, sensitive, creative, honest, and open recognition and acknowledgement of the perspectives, needs, and objectives of both researchers and communities as the basis for producing specific research. Thus, a crucial part of our proposal has been to generate collaborative spaces to creatively work with Afro-Ecuadorians' memories and co-design the space where these sounds will be reincorporated into the territories. It is in these spaces that we aim to collectively design and decide which sounds and memories should be included and how.

\section{The Devil in the African Diaspora}

The fact that a Christian order of priests was the leading enslaving company in Ecuador is not surprising. Christian religion was the main tool Spanish colonizers used in the Americas to exploit the different groups of people they subjugated and abused. This forceful introduction to Christianity included the belief in the existence of the devil (Thornton, 1998, p. 239). For Spanish colonizers, the devil was a real presence that should always be evaded. Importantly, they related African people-themselves and their practices-to the devil (Borja Gómez, 1998, pp. 113, 119; Díaz-Díaz, 2005, p. 32). Colonizers used religion to turn people into devil-fearing Christians and eradicate what they understood as the devilish practices of African people. In turn, enslaved people developed symbolic mechanisms to adapt to the colonial system in which they were forced to live (Borja Gómez, 1998, p. 140). One of these mechanisms allowed them a re-interpretation and adaptation of Christianity influenced by their African creation myths. For instance, in African myths, the "ontological dualism" of Christianity that would strictly separate good from evil is absent and this allowed black people to develop their own notion of a devil. This notion is based on the African belief of nothing being considered entirely good or bad but more precisely complex and multifaceted with a variety of traits (Borja Gómez, 1998, p. 132). Thus, for enslaved West African people, the devil could range from a figure of mirth, or protective buffoon with a caring and gracious side, to a source of evil or a powerful trickster (Borja Gómez, 1998, pp. 138, 169; Cedeño Canga, 2015 , p. 149; Taussig, 1980, p. 43). By appropriating the Christian notion of the devil and transforming it into a being with whom enslaved people could negotiate, play and whom they could even defeat, they were appropriating the enemy of their enemies as a mechanism of defence against the colonial order. That is, they were creating a new system where they temporarily transgressed the codes and meanings of the colonial social system where a new power relation was established (Borja Gómez, 1998, pp. 137-152). In this article, we focus on the relation of Marimba Esmeraldeña and Bomba del Chota to the non-human creature of the devil because it shows the ability of Afro-Ecuadorians to transform the official Christian narrative of the devil from an evil and invincible creature into a counter-narrative of a playful being with whom it is always possible to negotiate and whom it is even possible to defeat.

Our point of departure for collectively designing an artwork is the recorded testimonies of Marimberos and Bomberos regarding their relationship to the devil. Their testimonies were curated into a sonic composition; therefore, it is essential for the reader to listen to the composition before continuing reading (it is available here: https://vimeo.com/587009031). This sonic composition will be the main material to dialogically construct the space to re-incorporate these sounds and memories into the two territories. The dialogic process will happen in the form of creative workshops where people of all ages will be able to join in and listen to the sonic composition, while we walk in the jungle and the mountain and listen to the sounds surrounding and shaping the territories in the present moment. A discussion will be facilitated to question the significance of those sounds and stories, how they shape their territories, their relevance today, who should listen to the sounds and stories and why, etc. Also, Marimberos and Bomberos will be there to answer questions, tell stories and interact with the people. In the following section, we narrate some of these testimonies and discuss how they relate to our project of collectively re-shaping the public space to transgress the colonial order in Afro-Ecuadorian territories. That is, our aim is to collectively transform the space with the people inhabiting them into a space filled with specific values of liberation, justice, and freedom, rather than leaving it untouched. For this, we draw inspiration from critical thinking traditions in Latin America, such as participatory action research (Fals Borda, 1979), Freire's (2020) critical pedagogy, and decolonial research practices (Escobar, 2018; Rivera Cusicanqui, 1987, 2018). 


\section{The Devil in Marimba and Bomba}

De Friedemann and Arocha (1986, p. 416) cite the lyrics:

Los que están bailando / To those who are dancing

Bailen con cuidado / dance carefully,

A debajo de casa / because under the house,

Está el diablo parado / the devil is standing

As it has been discussed, Marimba and Bomba were perceived by colonizers as some of the Afrodescendants' devilish practices. On the contrary, according to what the elders used to tell the Marimbera Doña Maura Manuela Medina, who is also the healer of the community of Telembí (Esmeraldas), the Marimba came from God (López-Yánez, 2020). As can be heard at the beginning of the composition, Doña Maura mentioned that she had heard that some people say that Marimba belonged to the devil, but that she does not agree, because the elders used to love Marimba, and they were good people. However, although Marimberos and Bomberos do not consider Marimba and Bomba to be devilish practices as in the Christian figure of evil, some of the events do have a connection to the devil. For instance, the Bombero Don Ezequiel Sevilla, from the community of San Juan de Lachas (Chota-Mira), affirmed that elders used to tell him that some Bomberos, through performing Bomba, could visit hell and thus also the devil, and that they used to say that hell was a beautiful place full of beautiful women. It is important to mention that, usually, Marimberos talk about the devil and Bomberos talk about the minstrel (duende). However, according to some Bomberos, and also to Agier (2002), the minstrel is a transformation of the devil that represents his strengths and weaknesses. Thus, here we refer to the devil or the minstrel as the devil (Figure 3).

According to some Marimberos and Bomberos, unlike sacred events like masses in the Catholic Church, where it is very difficult for the devil to get in, the devil can get in more easily into events of Marimba and Bomba. When the devil reveals himself in such events, he constitutes a central force that affects the whole event in specific ways. According to the Marimbero Remberto Escobar Quiñónez, the devil chooses to go to Marimba celebrations to win souls, since Marimba is considered by the devil a moment where the pleasures of the flesh are enjoyed and impure thoughts arise (Escobar Quiñónez et al., 1997, p. 77). As shared by the Marimbero known as Papá Roncón from the city of Borbón (Esmeraldas), sometimes, the devil also likes being close to beautiful female Marimberas and Bomberas to flirt with them, make them fall in love with him or kidnap them (López-Yánez, 2020).

In most of the testimonies that have been gathered, Marimberos and Bomberos recount that during an event they opened themselves to the possibility of overcoming fear and confronting the devil, and once they confronted him, he was actually a being that mocked and played with them. They understood this playful and mocking attitude of the devil towards Marimberos and Bomberos as a provocation. For instance, as can be heard in the composition, both the Bombero Don Teodoro Mendez from the community of Tumbatú (Chota-Mira) and the Marimbero Don Remberto Escobar Quiñónez from the city of Esmeraldas narrate how the devil would challenge them to prove who the best performer of Marimba and Bomba is (Figure 4). They had to accept his challenge to get rid of him, and it was especially difficult because the devil is considered by some to be the best Marimba and Bomba performer. Interestingly, for Marimberos and Bomberos, being a good performer is not limited to being able to sing or play the Marimba or Bomba with virtuos ity but also to their creativity while doing so. Sometimes the devil wins, but most of the time Marimberos and Bomberos are the winners. If the devil wins, it means that the Marimberos or Bomberos either die or go mad. If Marimberos or Bomberos win, besides saving their life, they will increase their prestige since it would mean they are better performers than the devil.
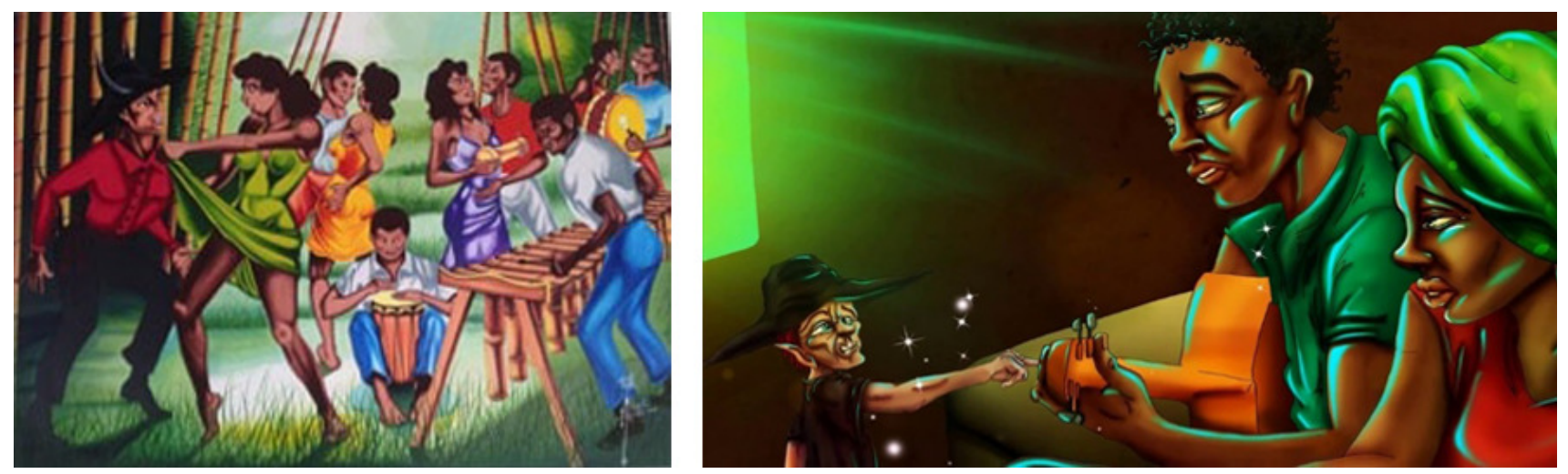

Figure 3. Graphic representations of the devil and the minstrel in Marimba Esmeraldeña and Bomba del Chota. From left to right: A painting of the devil in the middle of a performance of Marimba, by Esmeraldeño Alberto Acosta (photograph taken by María Gabriela López-Yánez during an exhibition in Esmeraldas, Ecuador, in 2017); an illustration by the Ecuadorian Iván Guamán of the minstrel talking to a Bombero (Guamán, 2015, p. 48). 

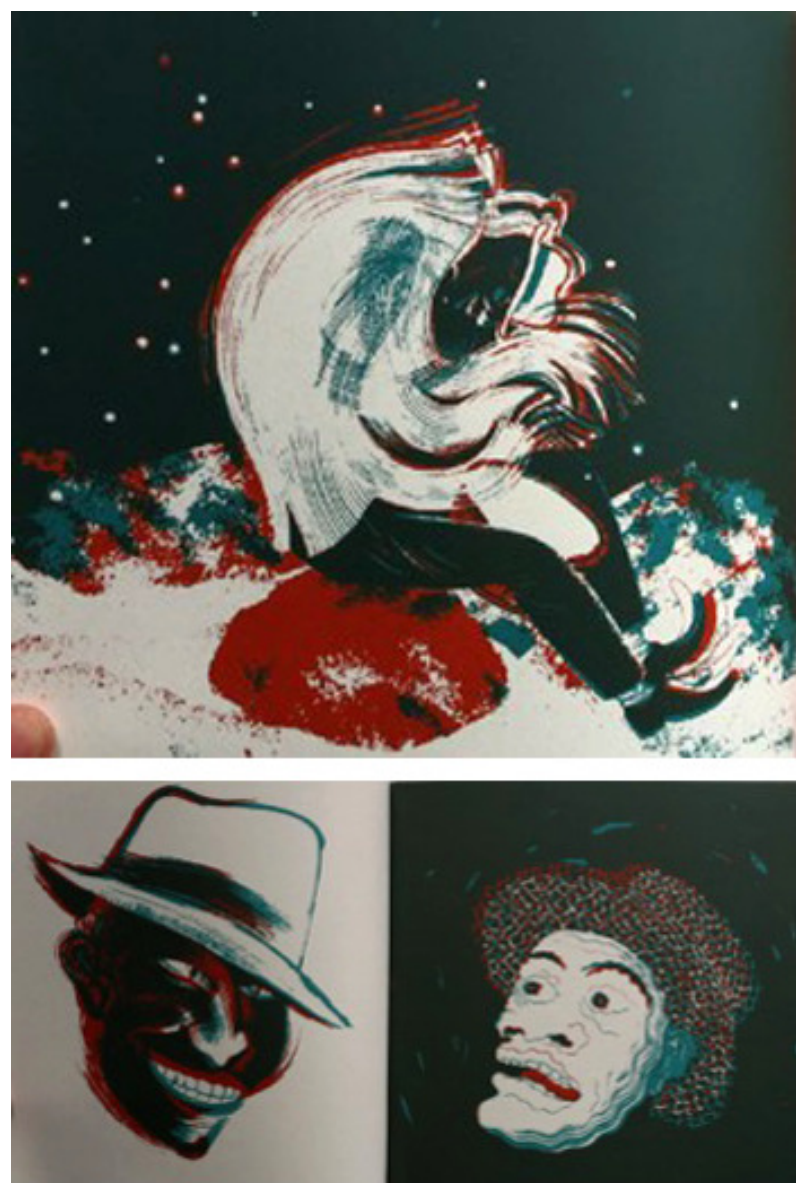

Figure 4. The Bombero David Lara and his encounter with the devil. Illustrations by Ecuadorian Marco Chamorro and the French Alice Bossut. From top to bottom: The devil playing the drum of Bomba in the middle of his battle with David Lara; David's and the devil's facial expressions in the moment David realises he did not walk towards the mountain with a man but with the devil (Chamorro \& Bossut, 2016).

Regarding the physical characteristics of the devil, there is a diversity of traits that he can have. According to the Marimberos Doña Medina, Nacho Caicedo, and Remberto Escobar Quiñónez, whose testimonies are included in the composition, the devil has two horns and a tail, dresses in red, and holds a massive trident. The Bombera Doña María Rogelia Minda, from the community of Tumbatú, said that when she saw the devil, he had animal-like legs and big teeth ( $R$. Minda, personal communication, 2018). However, according to Remberto Escobar Quiñónez, the devil has different looks. When the devil appears in a party, he dresses elegantly to hide his horns and his tail, but he always leaves the spurs on his boots visible (Escobar Quiñónez et al., 1997, p. 76). Similarly to Doña María Rogelia, the Marimbero Papá Roncón shared that once he was in a performance where the devil was floating, without touching the ground with his feet. The three Bomberas of the group "Las Tres Marías" from the community of Chalguayacu
(Pimampiro, Imbabura) affirmed that, when they saw the devil, he had a wooden leg (personal communication, 2013). Each of these traits was important primarily as a way of recognising the devil in an event of Marimba or Bomba. Thus, realising that someone was flying, had a wooden leg, or was of an unusual height would alert Marimberos and Bomberos to his presence.

Once the presence of the devil is acknowledged, the duty of a Marimbero or Bombero is to get rid of him as soon as possible. Sometimes, they make him go by force. Other times, they have other strategies. One of them is praying out loud specific prayers or incantations. However, since prayers are acts of magic, Marimberos and Bomberos cannot reveal the whole prayer but only a part of them or just the name. One of the most famous prayers used by Marimberos and Bomberos is the Credo al Revés (literary meaning "the creed read backwards") or the Padre Nuestro al revés (Our Father read backwards). As stated in Moschetto's (1995, p. 194), research about Afro-Esmeraldeño traditions, the expression Padre Nuestro al revés always refers to a prayer that is directed against the devil. Another prayer mentioned by some Marimberos is called Ave María Purísima (Hail Mary). Some of them, such as the Marimberos Rosa Huila and Remberto Escobar Quiñonez, also mentioned the religious phrase or incantation magnifica y en grandeza that has its roots in the Christian prayer called La Magnifica (The Magnificat). A prayer mentioned a few times by some Marimberos and Bomberos, like the members of the Bomba group "Las Tres Marías" and Escobar Quiñónez, is a prayer called El Tono de las Vacas (The Tone of the Cows), which is explained in detail in Escobar Quiñónez et al. (1997, p. 79).

One of the most engaging testimonies that shows the Marimberos' playful fearlessness concerning the devil comes precisely from a famous marimba song of Patacoré, played with the rhythm of Bambuco, and beautifully interpreted by Papá Roncón. In this Bambuco song, which is a central part of the sonic composition, a few verses that are part of the Afro-Esmeraldeños collective memories are included, the most essential one being: "Here comes the devil, let him come, because if he comes angry, I will make him laugh." Also, de Carvalho-Neto (1964, p. 93) affirms that a researcher named Chavez Franco saw a performance of Marimba in 1927 and that one of the verses he could hear was: "Here he comes the devil, let him come, if he comes alone, it is better for me." Whitten (1965) also registered the following verse: "Come hear the marimba. It chases the devil. I am the devil. I am going on a trip. Do not dance with me, because I might decide to stay with you." Another strategy to win a competition with the devil was to play specific tunes on the guitar. According to the Bombero Don Seberino Méndez, from the community of Chalguayacu, there used to be two guitar tunes that Bomberos could play to get rid of the devil. These were called Olmedo and Galindo. These tunes have been analysed in detail by de la Cruz Santacruz (2012, p. 140). 
As shown in the testimonies mentioned above, being able to defeat the devil is a source of pride for Marimberos and Bomberos. The Marimberos and Bomberos included in the composition expressed how pleased they felt when they defeated, or heard that someone else defeated, the devil. This sense of winning is directly related to overcoming their history of violence and dehumanization. As is beautifully expressed by García Salazar (n.d.) in the powerful testimony that ends the composition, the re-enactment of Afro-Ecuadorians' collective memories is what makes them "become once more what they were not before."

As we can see, there is a complex soundscape made of prayers, storytelling, chanting and music playing that Marimberos and Bomberos reproduce in connection to the devil. Moreover, this connection sustains a crucial space for playfully transgressing codes of colonialism and shapes the public space through a joyful and defiant experience of gathering together as a community. In other words, the existence of the devil within these territories maintains a particular connection to space and among people because through it, they creatively respond to an oppressive system that negates their existence. In the following sections we further discuss the decolonial possibilities of cohabitation that these soundscapes related to the devil can help support.

\section{The Decolonial Possibilities of the Soundscape Related to the Devil}

We frame our discussion within the notion of coloniality/decoloniality as a group of analytic and practical tools that allow us to propose potential mechanisms to re-focus on oral memories related to the devil as crucial elements of the process of resistance of Marimberos and Bomberos.

Coloniality (Mignolo, 2000; Quijano, 1992), or the so-called "colonial horizon of long duration" (Rivera Cusicanqui, 2012), refers to the hierarchical structure of domination that began during the period of colonialism and persisted even when that historical period ended. For instance, within coloniality, the only knowledge that has been recognised as legitimate is that from the "Western" world (colonizers). On the other hand, knowledge from populations such as Afro-Ecuadorians (colonized) is reduced to mythical and non-rational, and thus, non-important experiences. A group of examples of this low-hierarchy knowledge within a colonial system is Afro-Ecuadorian collective memories. These memories, including their relation to non-human creatures, were located in a lower hierarchy as being pagan and witchcraft, and thus, slowly erased. In this way, coloniality in the Americas has shaped how knowledge is constructed and legitimised. The coloniality of knowledge refers to the establishment of a Eurocentric approach in which there is a bias in knowledge that favours the development of knowledge from European civilisations over non-European civilisations. Importantly for this arti- cle, through the coloniality of knowledge the intergenerational transmission of an important number of collective memories related to Marimba and Bomba has been violently interrupted. According to López-Yánez (2020), this interruption has been historically achieved through banning (in the case of Marimba) and controlling (in the case of Bomba) these events. More recently, and as a continuation of these first modes of interruption, the lack of sustainable spaces of circulation of knowledge around Marimba and Bomba and their exclusion from the official art curriculum has also occasioned their continual weakening.

In opposition to this colonial oppression of AfroEcuadorian music and dance-based events, this article proposes the decolonial approach of re-locating the collective memories that coloniality has been trying to erase, but which keep existing in elders' testimonies. Decoloniality is understood here as the undoing of the damage that colonial modernity has caused, by confronting it and delinking it from the colonial matrix of power (Mignolo, 2011, p. xxvii). In this context, collective memories, particularly those related to the devil, represent a challenge by, or invitation from, past generations to re-signify and occupy their territories with joy and freedom. Using this lens of decoloniality, a collective design is proposed here consisting of the insertion of pieces of collective memories back into the territories where they existed and helped to shape them.

In this regard, a central part of our proposal is the understanding of sound not just as a mechanism to communicate information, but also as a way to shape worlds and give them specific meanings. Kanngieser, basing their work on language and sound theories, suggests that, through speaking and listening, a sense of belonging and a reconfiguration with each other and with the world arises (Kanngieser, 2011). In this article, we suggest that the disappearance of the sounds that used to call or at least commemorate the devil's presence in Marimba and Bomba events have transformed the public spaces of the jungle and the mountains. We understand public space as a collective form of inhabiting and creating meaningful relations that connect people to a place in specific, contested and negotiated ways. Through our proposal, we aim to carry these sounds back to those spaces as an active exercise of decolonizing them. Of essential interest to this article, collective memories have been gathered principally from previously recorded interviews and from López-Yánez's (2020) fieldwork conversations.

\section{The Proposal of Collectively Designing a Sonic Artwork Related to Memories}

The design of the artwork consists of two phases. First, the gathering of audio-recorded testimonies of elders around the devil in Marimba and Bomba taken from local archives and López-Yánez's long-term research, as well as the sonic composition based on this material. 
Second, the exposure of this composition to people in Afro-Ecuadorian communities, for them to choose and negotiate how, when, and where to re-incorporate these sounds.

The first phase, i.e., the gathering and creative process of the composition has already been concluded. This composition was generated based on a diversity of testimonies and songs related to the devil that were shared with López-Yánez over the last ten years of meeting a wide range of Marimberos and Bomberos, aged 53 to 91 years old, who had witnessed or inherited specific memories, and thus, building a relación de escucha with them. This relación de escucha allowed López-Yánez to finally audio-record them in 2018 and led to the creation of the sonic composition. In the same year, jungle sounds from both territories were also recorded by López-Yánez. The testimonies, music, and jungle sounds were recorded using the built-in microphone of the high sound quality digital voice recorder Zoom $\mathrm{H} 6$ for the ambient sound, and with two unidirectional microphones connected to the Zoom H6, one Rodeo NTG2 and one Rodeo NTG3, for the voices and music. The usage of this cutting-edge technology for fieldwork audio recording ensured the high quality of the material so that it could be used in the sonic compositions and preserved for future uses. Once the audio-recorded material was obtained, the sonic composition was created. Although most of the sonic material that was used included words, none of the information provided by these recordings is limited to words alone and/or their meanings, but also to their affective potential to communicate in specific ways through unique characteristics of, for instance, the voices' timbre, cadence, resonance, densities, and even silences.

In the process of creating the composition, both the semantic and affective characteristics of the audiorecorded material were considered. In many portions of the compositions, the semantic discourse is dominant, meaning that the narrative content of the voices is emphasised. For instance, one can point to specific narrations and testimonies of the historical and social contexts of Marimba and Bomba. In some parts, the affective discourse prevails, for instance, laughter, sighs, yells, musicalities, and other non-semantic sounds; and in some others, both characteristics are equally important. Following Lane (2006), the techniques used in each sound, or group of sounds, changed depending on the on-going dialogue with a group of Marimberos and Bomberos, the aim of the composition, and the quality and content of the available audio-material. Since the composition is a mixture of historical reconstruction and creative approach, the techniques used were diverse to accommodate different purposes, such as deconstructing the sounds of words to strengthen affective sensations related to the sounds produced, associating sounds to reinforce the semantic meaning of a word by the addition of a related sound or massing voices to reinforce different voices rhythmically repeating either the same sound or word. Also, in some other parts of the sonic composition, moments of silence represent portions of the collective memories of Marimba and Bomba that either we do not know about, we know about but were not included in this work, or that have been continuously erased.

As for silence, we follow Browning (2003) to propose new ways of approaching the past in a non-linear way by including not just the words per se but their rhythm of rising and falling, and silences. Interestingly, she emphasises the fact that silences should not be filled but highlighted, since these could represent possible moments of ruptures within specific historical contexts (Browning, 2003, p. 166). García Salazar, who also validates the existence of silence within Afro-Ecuadorians' collective memories, shares Browning's notion. He affirms that while some silences can be as much related to secrecy as to acts of resistance, others are specific ways of relating to the spiritual world (García Salazar \& Walsh, 2017, p. 19). Silence has a special meaning within Afro-Ecuadorians' collective memories; it is not just about keeping silent, but it is also about letting the brother, the sister, the mother, or the compadre (godfather of one's child or close friend) talk. Silence is also a way of sharing (García Salazar \& Walsh, 2017, p. 132). Thus, secrets could be a whisper or a silence-an absence of sound. These secrets and silences that García Salazar mentions are an essential part of the sonic corpus of Afro-Ecuadorians' collective memories and thus, will be interspersed in the proposed artwork between sections of spoken word and music. Silence will also be present in specific parts of the public space where the sonic artwork will take place as sections on the walking path or as sudden interruptions of the sounds. This will be done in order to represent either those collective memories that are not remembered anymore or those ones that, according to elder Afro-Ecuadorians, should not be shared widely. Moreover, the silence of what is not heard any more in specific places, such as the stories of the devil, will be the opening theme of the process of collaborative design of the sonic artwork.

\subsection{The Sound of Absence}

What does it mean to actively listen to the absence of beings in a place they used to inhabit? In the design phase, we aim to start the dialogues with the communities with this question. And we will also ask, can we listen to that which is no longer here and turn our attention to what has been lost by carefully listening to the silence? Although we want to bring back sounds to places where they used to be, we also want to challenge people to engage with the spaces by investigating and imagining what they cannot longer hear. What sounds have their parents and grandparents told them about? Silence can be a rich point of political reflection in a place shaped by a history of extermination and extinction, of erasing and muting (Kanngieser \& Beuret, 2017). 
We propose that this is the way to start building a public space. More than gathering people in one place, we also want to enable them to engage with the deep, shared history that connects them to that place (Calderón \& Huybrechts, 2020). And eventually, we want to encourage the construction of a place of freedom and liberation (Freire, 2020), such as the one opened by the Marimberos and Bomberos in their defiance of the devil. Again, we ask, by listening to the recorded memories, can we listen to the change that these places have suffered throughout time? We also want to question how they have been transformed by the colonial enterprise that disarms specific relations and keeps some creatures away. And to continue with that reflection, can sound intervene and make a difference in the connection among entities in an ecosystem? Can sound bring back entities that no longer inhabit those ecosystems?

Colonialism and capitalism affect, shape and change ecologies (Haraway, 1992; Kanngieser, 2020; Tsing, 2016). Esmeraldas is a territory deeply affected by pollution coming from plantations and mining, the rivers that are vital resources for the communities are very polluted, and it is the only Ecuadorian province whose inhabitants cannot access drinking water until now (López-Yánez, 2020). However, people also shape the land and respond to the currents of capitalism and colonialism. In the words of García Salazar and Walsh (2009, pp. 347-348): "The mother mountain and the mangroves are here because we are here, using these territories as spaces for life." To understand these spaces of life, it is important to note that the public space in the rural communities of the two ancestral territories is not circumscribed to a specific and delimited area. It is rather shaped by the paths people walk, and the times, the cautions and limits with which they move. A good way to understand this is through the presence and absence of a bird called Marimbero. According to López-Yánez's (2020) interview with the famous Afro-Ecuadorian Marimbero Don Nacho Caicedo, this bird used to sing for musicians, and they would imitate its sound. Through this imitation, they would learn how to play the traditional rhythms of Marimba. Nowadays, it is rare to find a Marimbero bird when one walks through the Esmeraldeño jungle. Has the Marimbero bird left the jungle-together with the devil-because they do not feel acknowledged (needed) anymore? Have both become extinct because of the rapid and uncontrollable environmental changes Esmeraldas has faced, which are unavoidably connected to the violence Afro-Ecuadorians have suffered with the silencing of their traditions?

Our proposal is to engage people in meaningful and critical reflections about the spaces they cohabit, and importantly, draw inspiration from their own history to creatively respond and transgress the colonial codes that shape and structure those spaces. There are examples of this kind of artistic intervention that have successfully engaged people in transforming oppressive codes. For instance, the artist Frances Negrón-Muntaner created the project Valor y Cambio in Puerto Rico, an interactive sound artwork that combines art and storytelling to work with a community currency that values community knowledge and skills instead of following colonial-capitalistneoliberal economic values. The installation inspired communities around Puerto Rico and USA to create their own community currencies (Negrón-Muntaner, 2020).

\subsection{What Could a Decolonial Public Space Look Like Today, Inspired by the Experiences of Resistance?}

In this article, we propose a disruption of the public spaces of the two Afro-Ecuadorian ancestral territories by returning the disappearing memories of the devil back to where they used to be played and listened to, for people to engage with the sounds and their history. We consider the returning of these memories an essential process of decolonizing knowledge around Marimba and Bomba. In this attempt, sound plays a central role. We are referring not just to the stories, but to the actual sounds (Kanngieser, 2011). We propose to bring back these sounds, with much of their strength, with some form of sound artwork. We understand the sound artwork as an immersive experience in which pre-recorded sounds are located in public spaces where they used to belong to, and which can affect the spaces themselves, including the human and non-human entities that visit them. Importantly, the primary participants of this artwork are Afro-Ecuadorians themselves. Thus, it will be held in their public, although intimate, space. As for the process of choosing the sounds of the artwork, we aim to do so in constant dialogue with a group of Afro-Ecuadorians of different ages and backgrounds. Specifically, the process will be to have this dialogue while listening to the sounds along different paths people walk in the jungle and the mountain. The dialogue will be guided by the elders who can still recall the recorded memories. Along the paths there will be gathering points where people will have the chance to talk to the elders and ask them questions. We will also have some questions for people to engage with the sounds, the silences, and their history.

By constructing the dialogue in this way, we want to bring together different generations to listen to the sounds and silences that shape their territories, not only humans but also other entities, such as the devil. We want to instigate the occupation of the spaces by inviting people to attune to the sounds and silences of their history.

The two ancestral territories are not empty spaces; they are full of deep stories where different entities have roots together in a common land. The Afro-Ecuadorians' relationships to these entities through the music and dance reproduced in Bomba and Marimba have shaped these practices, opening possibilities of joy and freedom amidst a story of oppression and violence. Our proposal for the collaborative design of a sound artwork seeks to deepen the understanding of the two music and dance based-events of Marimba and Bomba as 
practices that have shaped the common spaces that Afro-Ecuadorian people have inhabited. By doing so, we want to decolonise the idea that conceives these events as mere acts of folklore that happen on a stage, instead of living practices that interweave specific relations and shape the public space.

In this sense, we also understand that although we highly value this ancestral knowledge in specific ways, the creation of meaning is something that happens through the active engagement of people inhabiting the places. For us, it is crucial to break with the extractivist logic of extracting knowledge and taking it somewhere else to profit from it. The idea is to have that knowledge circulate within the communities (Calderón \& Huybrechts, 2020; Negrón-Muntaner, 2020). We propose a particular form of engagement of people with the territories that is not neutral but rather seeks the transformation of colonial dynamics. Our intention is to change how we see the world around us by critically challenging how we cohabit that world.

\section{Conclusion}

As shown by the above-mentioned collective memories, the relationship between the devil and Marimberos and Bomberos represents a clear way of transforming colonial experiences into strategies to "play" with hegemonic power. However, the colonial dynamics of oppression, exploitation, extractivism, and pollution have resulted in the absence of the devil from their public spaces, where he belongs. We propose a reintroduction of the devil into the territories to see if this relationship with him can inspire the construction of common experiences of joy and freedom. We want to experiment with the potential of sound to construct a public space by inviting people to attune themselves to their territories and to the different entities that have inhabited it.

We are aware that the pain and sadness of living in a world driven by the colonial enterprise in the Afro-Ecuadorian territories has deep roots and cannot be overruled in its entirety by an artwork. However, our aim is to contribute to the re-occupation of the public space in joyful and creative ways as a way of doing politics of the commons where people create their own codes and meanings. Furthermore, we anticipate resistance from the younger generation to engaging with their traditions, but we believe that the dialogue is necessary and young people can better engage with their history if they can use, transform, and question it in meaningful ways, rather than them simply being expected to accept its value. We believe that a decolonial approach needs to engage with the past in creative ways to affirm and value our existence in the present.

\section{Acknowledgments}

We would like to express our deep gratitude to the Afro-Ecuadorian Marimberos and Bomberos who have resisted throughout centuries of structural and systemic racism by cherishing and circulating their memories around the devil in Marimba and Bomba to new generations. Especial thanks to those who allowed us to learn from them.

\section{Conflict of Interests}

The authors declare no conflict of interests.

\section{References}

Agier, M. (2002). Identidad cultural, identidad ritual: Una comparación entre Brasil y Colombia [Cultural identity, ritual identity: A comparison between Brazil and Colombia]. In C. Mosquera, M. Pardo, \& O. Hoffman (Eds.), Afrodescendientes en las américas: Trayectorias sociales e identitarias. 150 años de la abolición de la esclavitud en Colombia [Afrodescendants in the Americas: Social and identity trajectories. 150 years of abolition of slavery in Colombia] (pp. 292-312). Universidad Nacional de Colombia; ICANH; IRD; ILSA.

Borja Gómez, J. H. (1998). Rostros y rastros del demonio en la Nueva Granada: Indios, negros, judíos, mujeres $y$ otras huestes de Satanás [Faces and traces of the devil in New Granada: Indians, Blacks, Jews, women and other hosts of Satan]. Editorial Ariel.

Browning, B. (2003). Choreographing postcoloniality: Reflections on the passing of Edward Said. Dance Research Journal, 36, 164-169.

Cabello Balboa, M. (1945). Verdadera Descripción y relación larga de la Provincia y Tierra de las Esmeraldas [True description and long-term relationship of the province and land of the Esmeraldas]. In J. Jijón y Caamaño (Ed.), Miguel Cabello Balboa (pp. 18-19). Editorial Ecuatoriana. (Original work published 1583)

Calderón, P., \& Huybrechts, L. (2020). PD otherwise will be pluriversal (or it won't be). https://doi.org/ $10.1145 / 3385010.3385027$

Cedeño Canga, J. J. (2015). Entre las quimbambas del Chocó Biogeográfico: Ruralidad, Identidad y Medios de vida de las comunidades negras de los ríos Santiago y Cayapas [Among the Quimbambas of biogeographic Chocó: Rurality, identity and livelihoods of the black communities of the Santiago and Cayapas rivers]. Facultad Latinoamericana de Ciencias Sociales; FLACSO Ecuador.

CEPAL, \& UNFPA. (2020). Afrodescendientes y la matriz de la desigualdad social en América Latina: Retos para la inclusión [Afrodescendants and the matrix of social inequality in Latin America: Challenges for inclusion]. Comisión Económica para América Latina y el Caribe. http://otramerica.com/comunidades/ afrodescendientes-en-bolivia/1181\%5Cninternalpdf://508/1181.html\%5Cninternal-pdf://510/ 1181.html

Chamorro, M., \& Bossut, A. (2016). A ritmo endiablado de Bomba: Una historia contada por los negros del 
Valle del Chota [With the devilish rhythm of Bomba: A story told by the black people of Chota Valley]. Comoyoko Ediciones.

de Carvalho-Neto, P. (1964). Diccionario del Folklore Ecuatoriano [Dictionary of Ecuadorian folklore]. Editorial Casa de la Cultura Ecuatoriana.

de Friedemann, N. S., \& Arocha, J. (1986). De sol a sol: Génesis, transformación y presencia de los negros en Colombia [From sunrise to sunset: Genesis, transformation and presence of blacks in Colombia]. Planeta Colombiana Editorial.

de la Cruz Santacruz, N. P. (2012). Fortalecimiento del desarrollo del pueblo afro del Valle del Chota a partir de la compilación de mitos, creencias, tradiciones $y$ sabidurías [Strengthening the development of the African heritage people of the Chota Valley using the compilation of myths, beliefs, traditions and wisdom]. Universidad Politécnica Salesiana.

Díaz-Díaz, R. A. (2005). Entre demonios africanizados, cabildos y estéticas corpóreas: Aproximaciones a las culturas negra y mulata en el Nuevo Reino de Granada [Among Africanized demons, councils and corporeal aesthetics: Approaches to black and mixedrace cultures in the New Kingdom of Granada]. Universitas Humanística, XXXII(60), 29-37.

Escobar, A. (2018). Designs for the pluriverse: Radical interdepence, autonomy and the making of worlds. Duke University Press.

Escobar Quiñónez, R., Valencia, L., \& Grupo La Caonita. (1997). Memoria Viva, Costumbres y tradiciones esmeraldeñas [Living memory, customs and traditions of Esmeraldas]. Municipio del Distrito Metropolitano de Quito.

Fals Borda, O. (1979). Investigating reality in order to transform it: The Colombian experience. Dialectical Anthropology, 4(1), 33-55.

Freire, P. (2020). Pedagogy of freedom: Ethics, democracy, and civic courage. Rowman \& Littlefield Publishers.

Fundación Azúcar. (2017). Informe alternativo: Examen de los informes presentados por los Estados partes en virtud del artículo 9 de la Convención [Alternative report: Examination of the reports submitted by the States who are parties under Article 9 of the Convention]. Fundación Azúcar.

García Salazar, J. (n.d.). Conferencia negra [Black conference]. Radio Antena Libre.

García Salazar, J. (2020). Cimarronaje en el pacífico sur [Marronage in the South of the Pacific]. Ediciones Abya-Yala.

García Salazar, J., \& Walsh, C. (2009). Derechos, territorio ancestral y el pueblo afroesmeraldeño [Rights, ancestral territory and the Afro-Esmeraldeño people]. In ¿Estado constitucional de derechos? Informe sobre derechos humanos Ecuador 2009 [Constitutional state of rights? Ecuador human rights report 2009] (pp. 345-360). Universidad Andina Simón Bolivar; Abya Yala.
García Salazar, J., \& Walsh, C. (2017). Pensar sembrando/sembrar pensando con el Abuelo Zenón [Thinking and planting/planting and thinking with Grandfather Zenón]. Ediciones Abya-Yala.

Guamán, I., \& Reyes, K. (2015). Cimarrón: Antología del Valle del Chota [Maroon: Anthology of the Chota Valley]. Ministerio de Cultura del Ecuador.

Haraway, D. J. (1992). The promises of monsters: A regenerative politics for inappropriate/d others. In L. Grossberg, C. Nelson, \& P. A. Treichler (Eds.), Cultural studies (pp. 295-337). Routledge.

INEC. (2010). Cartografía digital 2010 [Digital cartography 2010].

Kanngieser, A. (2011). A sonic geography of voice: Towards an affective politics. Progress in Human Geography, 36(3), 336-353.

Kanngieser, A. (2020). Weaponizing Ecocide: Nauru, offshore incarceration, and environmental crisis. The Contemporary Pacific, 32(2), 492-502.

Kanngieser, A., \& Beuret, N. (2017). Refusing the world: Silence, commoning, and the Anthropocene. South Atlantic Quarterly, 116(2), 363-380.

Lane, C. (2006). Voices from the past: Compositional approaches to using recorded speech. Organised Sound, 11(1), 3-11.

López-Yánez, M. G. (2020). Sounds of collective memories: A decolonial counter-representation of AfroEcuadorian Marimba Esmeraldeña and Bomba del Chota. Goldsmiths College, University of London.

Mignolo, W. (2000). Local histories/global designs: Coloniality, subaltern knowledges, and border thinking. Princeton University Press.

Mignolo, W. (2011). The Global South and world dis/order. Journal of Anthropological Research, 67(2), 165-188. https://doi.org/10.2307/41303282

Moschetto, P. (1995). El diablo y el arco iris: Magia, sueños y tabúes en Esmeraldas [The devil and the rainbow: Magic, dreams and taboos in Esmeraldas]. Ediciones Abya-Yala.

Negrón-Muntaner, F. (2020). Decolonial joy: Theorising from the art of Valor y Cambio. In T. Moura, M. Fernández, V. Page (Eds.), Theorising cultures of equality (pp. 171-194). Routledge.

Quijano, A. (1992). Colonialidad y modernidad/ racionalidad [Coloniality and modernity/rationality]. Perú Indígena, 13(29), 11-20.

Rahier, J. M. (1998). Blackness, the racial/spatial order, migrations, and Miss Ecuador 1995-96. American Anthropologist, 100(2), 421-430.

Rahier, J. M. (2011). Hypersexual Black women in the Ecuadorian "common sense": An examination of visual and other representations. Civilisations, 60(1), 59-79.

Rivera Cusicanqui, S. (1987). El potencial epistemológico y teórico de la historia oral: De la lógica instrumental a la descolonización de la historia [The epistemological and theoretical potential of oral history: From instrumental logic to the decolonization of history]. 
Temas Sociales, 11, 49-64.

Rivera Cusicanqui, S. (2012). Ch'ixinakax utxiwa: A reflection on the practices and discourses of decolonization. The South Atlantic Quarterly, 111(1), 95-109.

Rivera Cusicanqui, S. (2015). Sociología de la imagen: Miradas ch'ixi de la historia andina [Sociology of the image: Ch'ixi regards on Andean history]. Tinta Limón.

Rivera Cusicanqui, S. (2018). Un mundo ch'ixi es posible: Ensayos desde una presente crisis andina [A Ch'ixi world is possible: Essays from a present Andean crisis]. Tinta Limón.
Taussig, M. T. (1980). Slave religion and the rise of the free peasantry. In M. T. Taussig (Ed.), The devil and commodity fetishism in South America (pp. 41-69). University of North Carolina Press.

Thornton, J. (1998). Africa in Africans in the making of the Atlantic world 1400-1800. Cambridge University Press.

Tsing, A. (2016). Earth stalked by man. The Cambridge Journal of Anthropology, 34(1), 2-16. https://doi. org/10.3167/ca.2016.340102

Whitten, N. E. (1965). Class, kinship and power in an ecuadorian town. Stanford University Press.

\section{About the Authors}
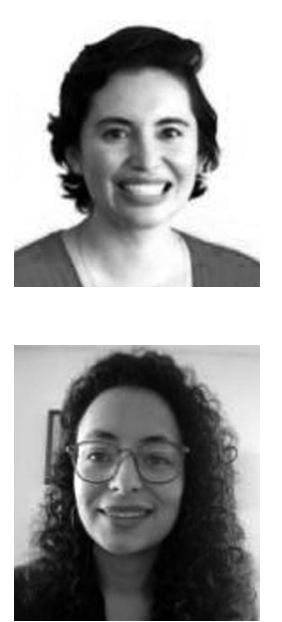

María Gabriela López-Yánez is an Ecuadorian performing arts researcher and artist. She has worked extensively on staging and in academic research of Afro-Ecuadorian music and dances. Gabriela holds a PhD in performing arts from Goldsmiths, University of London (UK), and an MA in dance from the University of Malaya (Malaysia). She has presented her work in Asia, Europe, and Latin America. Currently, she is a full-time lecturer at Central University of Ecuador and liaison officer for Ecuador and part of the Latin American outreach committee of the ICTM (International Council of Traditional Music).

María Paz Saavedra Calderón is a sociologist researching the intersecting politics of care, knowledge, and time. She has a PhD in interdisciplinary studies from the University of Warwick. Her research follows the reproduction of situated, embodied, and inter-generational knowledge in more than human worlds. Particularly, her work focuses on the politics of knowledge production in traditional practices of care and healing. She also works with community-based projects, developing pedagogical tools to generate communities of learning that weave together different local knowledges and practices. 